\title{
Familial occurrence of tumours of the choroid plexus
}

\author{
C P Zwetsloot, J M Kros, H D Paz y Geuze
}

\begin{abstract}
The case histories of two children of consanguineous parents with papillomas of the choroid plexus are presented. Although exogenic factors in the genesis of these neoplasms can not be excluded, autosomal recessive inheritance is proposed.
\end{abstract}

Neoplasms of the choroid plexus comprise less than $1 \%$ of all cerebral tumours. These tumours mainly affect children, with the highest frequency in the youngest age groups. ${ }^{1}$

Malignant development of plexus papillomas is seldom seen. ${ }^{2}{ }^{3}$ Familial occurrence of these tumours is extremely rare; there are two published reports, ${ }^{45}$ each describing a family with two affected sibs.

Department of Neurosurgery, University Hospital 'Dijkzigt', Rotterdam, The Netherlands.

C P Zwetsloot, H D Paz y Geuze

Department of Pathology, Erasmus University, Rotterdam, The Netherlands.

J M Kros

Correspondence to Dr Zwetsloot, Department of Neurology, Streekziekenhuis 'Waterland', Postbox 250, 1440 AG Purmerend, The Netherlands.

Received for publication 19 September 1990.

Revised version accepted for publication 27 November 1990.
In the present report, a son and daughter of consanguineous parents are described. The choroid plexus papillomas reached different degrees of malignancy in each child. The case histories and pathological examination of the tumours are presented and the possible heredity is discussed.

\section{Case reports}

CASE 1

A 13 month old boy was admitted because of slight psychomotor retardation, hypertonia of the legs, and a rapid enlargement of the head circumference. Examination showed a large head (OFC $49 \mathrm{~cm},<97$ th centile). The child showed a preference for using his right side. Furthermore, he was unable to sit up or to turn over.

A CT scan showed a large tumour in the temporal part of the right lateral ventricle, enhancing with contrast. Invasion of the surrounding brain tissue was suggested.

The patient died during the operative removal of the tumour, and necropsy was not permitted. Histopathological examination of the operation specimen showed a choroid plexus carcinoma (fig 1).

\section{CASE 2}

An 11 month old girl was admitted because of

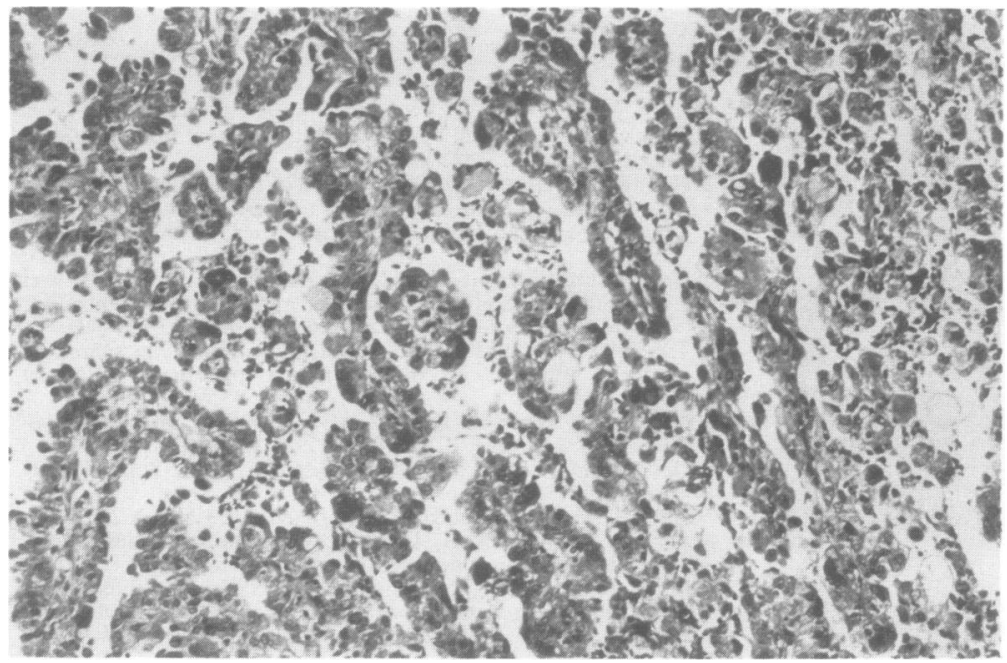

Figure 1 This tumour represents a carcinoma of the choroid plexus ('malignant plexus papilloma'). Although a basic papillary structure is recognisable, considerable anaplasia of the neoplastic cells is seen $(H \mathcal{E} E)$. 


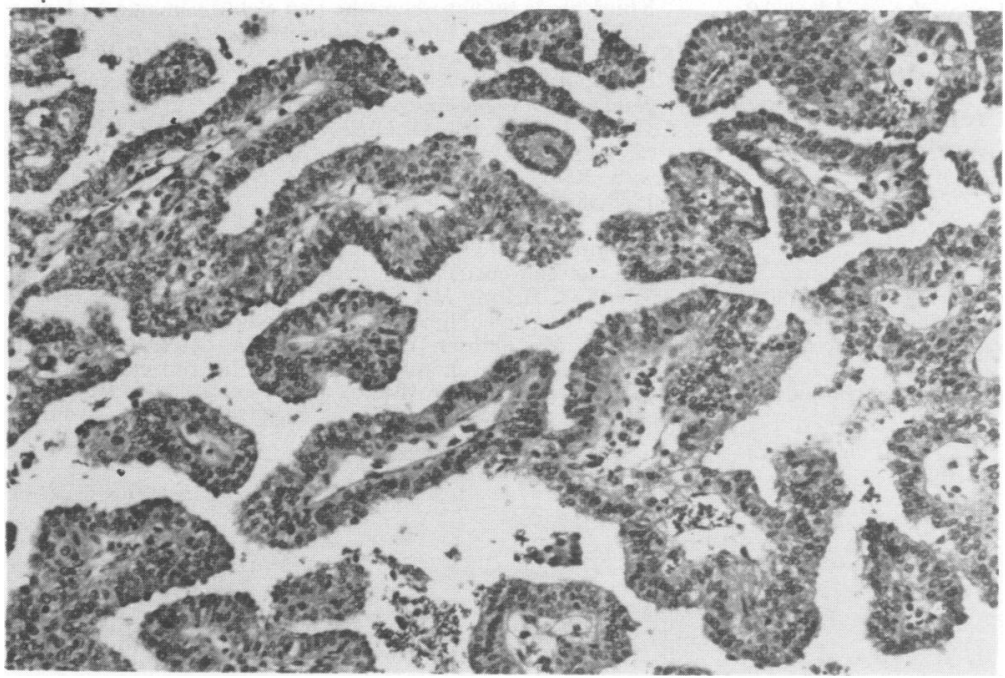

Figure 2 A classic choroid plexus papilloma: a branching vascularconnective tissue axis with an epithelial surface of cuboidal or cylindrical cells, slightly more cellular than the epithelium of normal choroid plexus $(H \mathcal{E} E)$.

I

II

III

IV

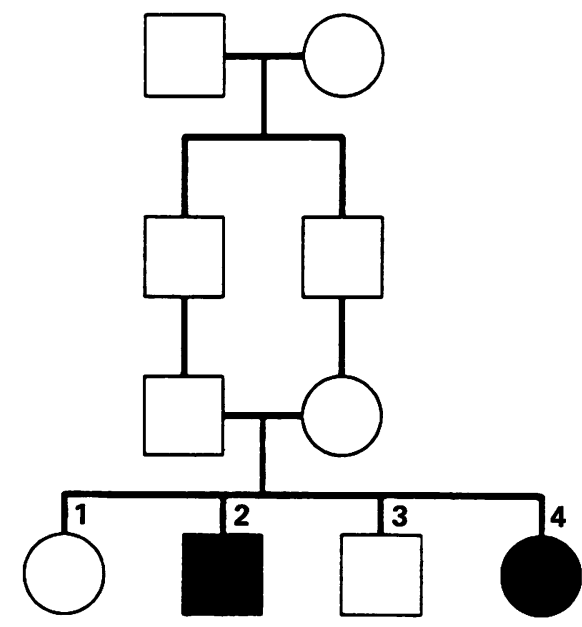

Figure 3 Family pedigree.

frequent vomiting and a rapid increase of the skull circumference. The OFC was $49 \mathrm{~cm}$ ( $>97$ th centile). She showed a slight left sided spastic hemiparesis.

CT scan showed a large tumour in the right temporal part of the lateral ventricle. Angiography detected a slight tumour blush in the ventricle, without pathological vessels. The tumour was removed and postoperatively several epileptic seizures were treated with phenytoin. A slight left sided hemiparesis and a left sided hemianopia remained. Apart from slight psychomotor retardation, she is doing well.

Histopathological examination of the operation specimen showed a choroid plexus papilloma, without obvious signs of malignancy (fig 2).
The parents are consanguineous (fig 3) and both are healthy. They have two other children, who, so far, are developing completely normally. There is no family history of brain tumours, or tumours of any other kind. The pregnancies resulting in the affected sibs were normal; the mother did not suffer from any illness, nor did she take any medication.

\section{Discussion}

Tumours of the choroid plexus are relatively rare. An association with viral infection, as shown in an animal model by Brinster et $a l^{6}{ }^{6}$ or with other, as yet unknown, exogenic factors, has not been established in humans.

The familial occurrence of several cerebral tumours has been reported, ${ }^{7}$ as has an association of brain tumours with inherited syndromes such as von Recklinghausen's disease and tuberous sclerosis, or with tumours of other organs in the familial cancer syndrome. ${ }^{5}$ Tumours of the choroid plexus have been reported in four cases of Aicardi syndrome ${ }^{8}$ and it has been suggested that these neoplasms might be specific for this X linked syndrome. The present finding of the occurrence of choroid plexus papillomas in sibs of consanguineous parents supports the hypothesis of genetic predisposition to the tumours. No consistent relation of tumours of the choroid plexus with other cerebral neoplasms has been established, nor with other tumours elsewhere in the body, although sporadic combinations in families have been described. $^{7}$

Two other case reports of familial occurrence of choroid plexus papillomas have been published. In one, the occurrence of a benign plexus papilloma in a boy, detected at the age of 2 years, and his sister, diagnosed at the age of 4 years, was described. ${ }^{+}$The 
second report deals with a girl of 9 months and her 10 year old brother. Interestingly, both children had the malignant variant of choroid plexus papilloma. ${ }^{5}$

Since the parents in the present report are consanguineous, autosomal recessive inheritance of the choroid plexus papillomas seems most likely.

1 Laurence KM. The biology of choroid plexus papilloma in infancy and childhood. Acta Neurochir (Wien) 1979;50:79-90.

2 McComb RD, Burger PC. Choroid plexus carcinoma. Report of a case with immunohistochemical and ultrastructural observations. Cancer 1983;51:470-5.

3 Gullotta F, de Melo AS. Das Karzinom des plexus choroideus.
Klinische, lichtmikroskopische und elektronenoptische Untersuchungen. Neurochirurgia (Stuttg) 1979;22:1-9.

4 Komminoth R, Woringer E, Baumgartner J, Braun JP, Le Maistre D. Papillome intraventriculaire familial: caracteristique angiographiques. Neurochirurgie 1965;11:267-72.

5 Coons S, Johnson PC, Dickman CA, Rekate H. Choroid plexus carcinoma in siblings: a study by light and electron microscopy with Ki-67 immunochemistry. If Neuropathol Exp Neurol 1989;48:483-93.

6 Brinster RL, Chen HY, Messing A, Van Dyke T, Levine AJ, Palmitter RD. Transgenic mice harbouring SV40 T-antigen genes develop characteristic brain tumors. Cell 1984;37:367-79.

7 Tijssen CC, Halprin MR, Endtz LJ. Familial brain tumors. The Hague: Martinus Nijhoff, 1982:143-68.

8 Robinow M, Johnson GF, Minella PA. Aicardi syndrome, papilloma of the choroid plexus, cleft lip and cleft posterior palate. $\mathcal{F}$ Pediatr 1986;104:404-5. 